Historic, Archive Document

Do not assume content reflects current scientific knowledge, policies, or practices. 

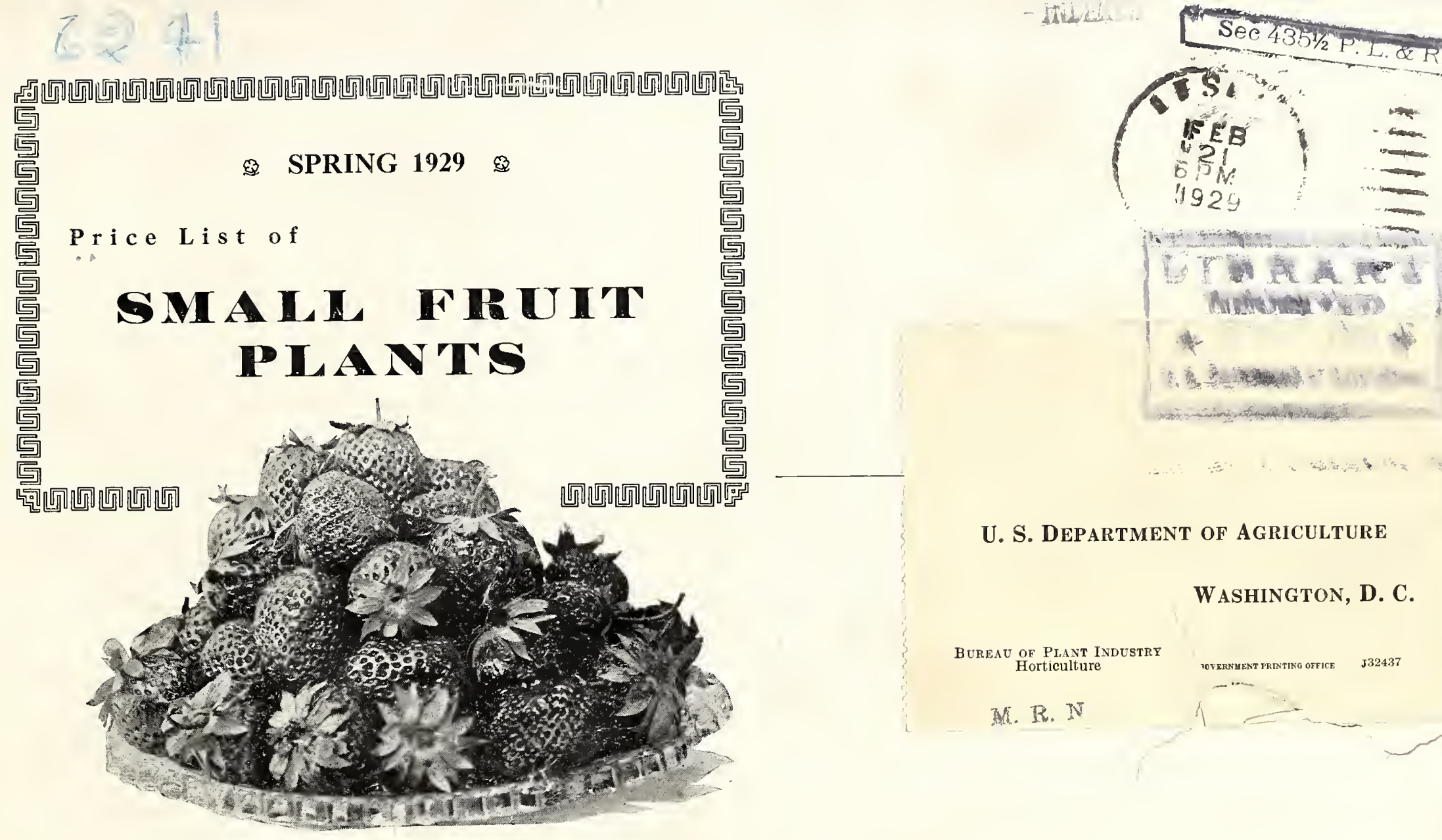

Sec/2Ju

(1) ....

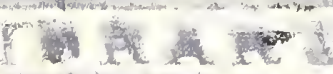
Molntwat - 4

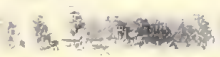

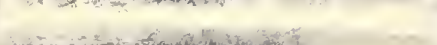

U. S. Department of Agriculture

Washington, D. C. BUREaU OF Plant INDUStry

TOVIRNYENT PRINTINO OFFICE J J32437

Th. R. N

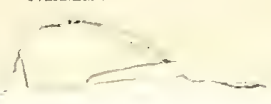

THE E. W. POT'I'ER COMPANY

LES L I E, M I C H I G A N 


\section{SEASON 1929}

FRIENDS :-

Another season for sending our catalog has arrived. We feel swe that it will interest you as it gives you the opportunity to procure-some of the strongest and most productive fruit plants it is possible to grow, at a reasonable price.

We know we have the finest stock of plants we have ever grown and visitors from all parts of the country say that our plants are the healthiest and strongest plants they have ever seen.

Buying berry plants, or any other Nursery stock, involves a large element of faith. After the plants are received and planted it takes a year before you are positive of the quality and value of the plants you have purchased, which makes it very ne:essary that you are sure that the grower with whom your order is placed is reliable, and sends out only plants that are true to name, free from disease and productive.

We wish it were possible for every one of our customers to examine our plants before they buy, but as long as it is impossible we want you to know that our GUARANTEE IS-Our plants are strong, healthy, free from disease, full count, and true to label. That they are freshly dug, properly packed, and promptly shipped.

We earnestly solicit your patronage and wishyou a most prosperous NEW YEAR.

Yours very truly,

The E. W. POTTER COMPANY.

\section{Read What Others Say}

Gents.:

Lenawee Co., Mich., May 5th, 1928.

I received the Dunlap and set them yesterday, also the Mastodon and set them this morning. Plants are all in good condition. I wish to thank you for your quick service and square deal.

Sincerely yours,

C. E. FINCH.

Kalamazoo Co., Michigan, May 14th, 1928. Dear Sirs:

We received four baskets of plants and they are all in good condition. Thanks.

$$
\text { Yours truly, }
$$

$$
\text { Cass Co., Nebraska, May 1st, } 1928 .
$$

'The E. W. Potter Co.,

Leslie, Mich.,

Dear Sir :

The strawberry plants arrived Monday and they were all O. K.

$$
\text { Yours very truly, }
$$

JULIUS A. PITZ.
Dear Sirs :

Marion Co., Ind., April 27th, 1928.

Received my plants and am well pleased. Please send me another collection the same as the ones you sent.

Yours truly,

PORTER APPLE. Dear Sir :

Breckenridge Co., Ky., April 19th, 1928.

I received the strawberry plants in good condition and all O. K. and am well pleased with them.

Respectfully,

CLYDE SIMMONS.

Dear Sirs:

Meade Co., K., April 9th, 1928.

I sent you an order a few years ago aite' I had a fine bed of strawberries from them, they ripened at different times, please send me the following orderYours truly,

MRS. J. W. SIMMONS. 


\section{Instructions to Purchasers}

\section{ORDER EARLY}

It will insure you getting the varieties you want and it will help us to get your plants shipped promptly when you want them.

PLEASE remit by P. O. Money Order, Express Order, Re ristered Letter, or Bank Draft.

\section{LOST ORDERS-}

All orders are acknowledged by postal card same day received, but if you should not hear from us in a reasonable length of time after sending an order, PLEASE IVRI'TE PLAINLY, giring full particulars, NAME AND ADDRESS.

Once in a while an order is lost, but it usually is caused by the customer failing to give the full address. Therefore, PLEASE WRITE PLAINLY, especially your name.

TERMS:-Payment must be made before shipment of plants. If not convenient to remit entire amount when order is sent remit not less than one-fourth of the amount of the order and your order will be booked and held for you and you can remit the remainder when convenient, before shipment of plants.

WE GUARANTEE the safe arrival of plants and in good condition if sent by mail or express by May 1 st.

WVE TAKE the greatest care to have all plants true to name and seldom ever have a complaint, but should any prove otherwise than represented. We will not be responsible tor any amount greater than actually paid me for the plants.

CLAIMS, if any, must be made on receipt of plants when they will be carefu1!y examined, and if just, made satisfactory.

FOR OUR RESPONSIBILITY address with stamp the People's Bank, Lesilie, Michigan, postmaster, express agent, or any official, professional or business man of the same place.
WE MAINTAIN OUR GRADE by a careful selection of stock plants, and right method of propagation from year to vear, that tend with such a soil to produce stock of the greatest health and vigor, striving for the ideal fruiting row and perfect fruit from any plants that may be left unsold.

OUR PLANTS ARE FRESH DUG as wanted, nicely trimmed, ready for planting, carefully re-sorted and tied in bunches of 25 ; roots washed in cold water if necessary to make them clean, and packed with live moss in new handle baskets lined with oil paper, or in light rentilated crates, in such a manner that we guarantee safe arrival in good condition by express or mail to all parts of the United States. Plants by freight at buyer's risk.

TRUE TO NAME. ITe take great pains to have stock trie to name and hold ourselves ready upon proper proof to refund money or replace any that prove untrue; but it is mutually agreed that we shall not be liable for a greater sum than the amount paid for such stock.

SUBSTITUTION. Early in the season we have everything listed in this catalogue, but late in the season usually sell out of some varieties. In case we are out of varieties ordered please say if we shall substitute some variety of same season, suitable for your locality. We always notify customer if we have time to receive your answer before you wish plants shipped, but in case you do not request us to substitute we shall return the amount for the plants we do not have.

OUR PRICES AVERAGE LOWER than can be found elsewhere, when quality of stock and guarantee conditions are considered. Our references for responsibility are ample. You take no risk whatever. See elsewhere a certificate of health from the State Department of Agriculture. Read our unsolicited testimonials. We invite investigation at all times.

\section{Cultural Directions}

\section{MATING-}

All strawberry blossoms are either staminate-also called perfect-or pistillate, generally called imperfect.

The imperfect varieties which are marked (Imp.) in cata$\log$, shovild have a perfect variety, marked (Per.) set every third or fourth row to properly pollenize the blossoms of the imperfect sorts.

There seems to be a mistaken idea with some that this mixing of varieties is necessary with the perfect as well as the imperfect sorts; but this is not so. The perfect are selfpollenizing, and bear as well if set by themselves.

\section{TIME TO SET PLANTS}

Early Spring is the logical, natural, most successful and satisfactory time to set Strawberry plants. So don't neglect setting some plants this Spring thinking you can make it up by early Fall planting. It can't be done.

How early? Just as soon as weather permits getting ground ready.

IVe are anxious at all times to please our customers, who in some way fail to get their plants in the spring, by sending them a few in the fall. However spring is by far the best time to plant strawberries. Spring planting is preferred because weather conditions are more favorable and because the plants come into bearing the next season. Fall set plants have to go through two winters before they start to fruit and the effect of winter is never beneficial to their plantation. To those whs are unfortunate and do not obtain their plants in the spring, we will gladly supply their needs at double the trice in catalog.

\section{NORTHERN GROWN PLANTS-}

A strawberry plant is never in so prime a condition as when fully grown, matured and dormant. Our friends in the South have recognized that our Northern grown plants are safer to set, because of their more dormant condition on arrival. while commercial growers in the North and IVest would not think of setting Southern stock of a more advanced growth. We also hold that while the strawberry will grow and thrive nearly everywhere, the North is its natural home, where it fits the conditions more naturally for a higher derelopment.

WE SHIP PLANTS to Southern customers during mild weather any time after they receive this catalogue, and to the North as late as the 15th of May, but for all sections it is advisable to order early, and name date of shipment as early as you can use the plants. Plants shipped early have less foliage, can be packed lighter, and if planted almost always do well.

OUR SHIPPING SEASON begins with the southern orders, as soon as frost is out of the ground in spring. often in March. We aim to set out plants in early April. If ordered late in the season, it is always best to name a second or third choice in case : variety is sold out. or leave it with us, stating soil conditions and other particulars. We will do our best to please you, but order early and have plants come early, if you can.

\section{REMOVING THIE BLOSSOMS-}

Strawberry plants that are set out this spring should not be allowed to bear fruit until the following spring. The blossoms should be pinched off, for to let them ripen fruit the first year would weaken the growth of the plants and is liable to kill them. Just as soon as you remove the blossoms your plant starts to work building up a root system. The heavy, vigorous root system is essential to enable the plant to come to its fullest possibilities of production.

NUMBER OF PLANTS REOUIRED TO SET AN ACRE$1 \times 1$ foot, $43,5604 \times 1$ foot, $10,8905 \times 3$ feet, $2,9046 \times 5$ feet, 1,425 $2 \times 1$ foot, $21,7804 \times 2$ feet, $5,4455 \times 4$ feet, $2,1786 \times 6$ feet, 1,210 $2 \times 2$ feet, $10,8904 \times 3$ feet, $3,6306 \times 1$ foot, $7,1607 \times 1$ foot, 6,122 $3 \times 1$ foot, 14,250 $4 \times 4$ feet, $2,7236 \times 2$ feet, $3,360 \quad 7 \times 2$ feet, 3,111 $3 \times 2$ feet, $7,2605 \times 1$ foot, $8,7126 \times 3$ feet, $2,420 \quad 7 \times 3$ feet, 2,074 $3 \times 3$ feet, $4,8405 \times 2$ feet, $4,3563 \times 4$ feet, $1,8157 \times 4$ feet, 1,555 


\section{How To Grow Strawberries}

Any one who will take reasonable care of strawberries, are sure to grow some fruit. We have never in all our years experience had a complete failure. There are no certain rules how strawberries should be grown. Keep them free from weeds and you will have plenty of berries. There is no other fruit you can plant that will bring results as quick as strawberries. Everyone who has a bit of land ought to plant them. We have the varieties that will pay you to plant. Try a few and be convinced.

\section{STRAWBERRIES WE GROW}

\section{ABINGTON (Per.)}

We have fruited Abington for years and find it a strong grower, with large luxuriant foliage. The fruit is large, quite similar in size and shape and color to Sharpless, but more abundant. (Mid-season.)

\section{AROMA (Per.)-}

One of the most popular late varieties. A good plant and a good bearer of large, handsome, fruit bright red in color: uniform roundish heart shape, firm and of good quality. Somewhat resembles Gandy in appearance. A choice variety and reliable.

\section{AUGUST LUTHER (Per.)-}

A good grower and reliable. Fruit large, glossy, bright red, firm and of good quality. This berry comes early, always making a good crop-before berries lower much in price. and for several years has been our choice for early market among the standards.

\section{BUBACH (Imp.)-}

Fruit large, moderately firm, good color and quality well known standard variety; productive and reliable. Mid-season. We are nearly always sold out of this variety before the season is over.

\section{BEDERWOOD (Per.)-}

Well known standard early market variety. A tough, healthy grower. Very successful especially in the west prairie country. Fruit medium to large size round, bright red, good quality. A good carrier and very productive.

\section{CORSICAN (Per.)-}

This is a favorite variety especially around Rochester, N. Y. The plants are large and good growers. Fruit large, longish heart shape, good quality: stands shipment well. Midseason. Very similar in plant and fruit to Uncle Jim. A good variety.

\section{CHESAPEAKE (Per.)-}

If this variety was a better plant maker it would be the leading late berry, for it has them all beat for size, productiveness and quality. We have tried it on all kinds of soil, but fail to get a good plant row. We hear similar results from other sections. The berry is large and regular in shape; color bright red. Quality much better than Gandy.

\section{DR. BURRILL (Per.)-}

This variety stands among the very best in the mid-season strawberries. Several dealers say as good as Dunlap or better. It resembles Dunlap in many ways. It is exceedinigly productive. of medium to large, well shaped, glossy red. Through and through we have yet to hear a poor report on Dr. Burrill.

\section{EXCELSIOR (Per.)-}

The well known standard early market variety. Plants vigorous, making many runners. Fruit medium to large size; round; dark red; firm; quite tart. Reliable and productive.

\section{EARLY OZARK (Per.)-}

Early. The introducer of this berry says it is a cross between Excelsior and Aroma. He further states that it is a perfect bloomer and has very large blossoms that are rich with pollen. It is the largest extreme early variety I have ever tested. The plants grow strong and are healthy. The fruit is firm, excellent flavor and good color, being bright red, about the same as the Aroma. 't is said to be very productive. The fruit is large, good color, and firm.

\section{GANDY (Per.)-}

Fruit large, firm, high quality and handsome. A good grower and productive. The well known standard late shipping berry.

\section{BRANDYWINE (Per.)-}

Fruit large, dark red, quite firm, good qualit-y. Not always at its best in some sections, but a good miety in others; recuiring strong loam soil and high cultuie for best results. Merium late.

\section{CAMERON'S EARLY (Per.)-}

Extra early. This fruit is of good size for so early a berry; medium red in color and of good quality. A vigorous grower, with a tall foliage to protect the bloom from late frosts. Productive and reliable.

\section{CLYDE (Per.)-}

Very productive. Fruit large, round, bright glossy red. Large, healthy plants. Well known standard market variety. Mid-season.

CAMPBELL'S EARLY (Per.)-

Very early. This variety produces a good crop of large bright red berries. Worthy of trial.

COOPER (Per.)-

Mid-season. Plants are strong growers and very productive. The fruit is large, beautiful in color and has a delicious flavor.

\section{COMMONWEALTH (Per.)-}

Very late. James Munroe (the introducer) in his description says the Commonwealth is the outcome of the desire and effort to produce a berry that would lengthen the strawberry season. In it we have a berry that is as large as the largest, as productive as any, has fine flavor, as solid, and as dark a color as any. The plant is a strong grower, but not so rank as some. The fruit is large, firm, dark color and very handsome. Later than Gandy.

\section{GLEN MARY (Imp.)-}

Fruit large, dark red, quite firm and good quality. A good grower, productive and reliable. This variety has small stamens, sufficient for itself, but not to retilize adjoining pistillates, and so we class it as an imperfect bloom. Mid-season to late. GIBSON (Per.)-

This is not the old variety of that name which orioinated in eastern New York several years a,go, but a distinct variety of local fame. The berry is large and regular in shape, holding its size well to the end of the season. Color rich red. Flavor is neither too sweet nor too sour, but just right for canning. It makes a good plant row and is worthy of trial. HOWARD NO. 17 (Per.)-

Fruited here for the first time. Produced good size of fruit of fair quality. Large, stocky plants, making a good fruit row. Worthy of trial.

HAVERLAND (Imp.)-

Very productive. Large fruit, rather long; bright light red; firm, good quality. Plants large and vigorous. Well known standard variety and reliable. Season early to late.

\section{KING WEALTHY (Per.)-}

Very late. A new variety. Our introduction. Makes good fruit row. Has a strong staminate blossom, fruit large, handsome, well shaped, and dark red. Fine for canning. Worthy of trial.

\section{KELLOGG'S PRIZE (Imp.)-}

This Pistillate variety is claimed to cozer a long season. After giving it a good trial we find it to be a variety of great merit. It was one of the best varieties we fruited the past season. The plants are strong growers and very productive. The fruit is high color, fine flavor and very large. Quite late LUPTON (Per.) -

Late. A large very handsome berry and an excellent shipper. The berries average about as large as Chesapeake. MARSHALL (Per.)-

A standard of quality. Very dark red; heart shape, firm and of high quality. A moderate plant maker of large, stocky plants. 
PARSON'S BEAUTY (Per.)-

A good healthy grower and an munense cropper of large solid, dark red berries of good form and quality. There is probably not a variety among the standards that will outrield it, or a more reliable. A first-class variety, with a long season.

PENNELL (Per.) -

F....it large, nearly round: dark, rich color: firm and of the rery higkest quality. We think more of the Pennell every rear. It always aears abundantly, and is one of the rarieties to which we direct riends who risit us at fruiting, who want something extra fine. Grow Pennell on strong loam and be surprised with the large size and excellence of this berry. A.1 all-season variety.

\section{PRIDE OF MICHIGAN (Per.)-}

Mid-season. From Mr. Baldwin of Bridgman. There seem to be two varieties by this name, but as the Kellogg strain is similar if not identical with New York, which was discarded by us some time ago, we will only offer the Baldwin strain. The berries are large, rather oblong, rery bright red. glossy, and beautiful; it being rery firm, makes it an excellent shipning berry. The plant is vigorous, making a good fruiting row in any kind of season.

\section{PREMIER (Per.)-}

An early variety, being large of extra good quality, and color being fine, which makes it a good shipping berry. Te consider this one of the larger of the earlier varieties. The berries are firm and beautiful in form and have few weak points. Has extra long season and is worthy of trial.

\section{ST. LOUIS (Per.)-}

While some claim this rariety is a second early, we find it extra early and one of the first to ripen. We have been highly pleased with it for some time and can recommend it as Queen of Earlies. This berry is not firm enough for long shipping. but as it has so many good points every grower should plant some. Mr. Batuer, the introducer, clains to have grown them so large that twelve of then would fill a quart basket. As grown here, it makes a strong, healthy plant, with plenty of rumers. Fruit very large for such an early berry. Light red color, nearly round and good quality.

\section{STEVEN'S LATE CHAMPION (Per.)-}

A variety that is a splendid, healthy grower, with tall, dark green foliage and long runners. The fruit is large and fine, resembling Gandy. Firm and of goorl quality, outyielding Gandy here last year and selling at the lighest prices. It is certainly a good variety.

\section{SAMPLE (Imp.)-}

Standard market variety. Mid-season to late. Fruit large, roundish conical; bright glossy red: moderately firm and of good quality. A good grower. Productive and reliable.

\section{SENATOR DUNLAP (Per.)-}

This variety has given general satisfaction in almost all sections and all kinds of soil, and the demand for plants increases each season. It makes plants of only medium size but tough and hardy, with long roots and a suprising capacity for enduring hardships. It is very productive and usually matures every berry. They are of good size, bright glossy red, and of excellent quality. It is a first-class shipper and retains its brightness after being picked. It ripens earty and continues a long time in fruit. It is grown largely as a commercial berry.

\section{UNCLE JIM (Per.)-}

This variety is an excellent grower of large, stocky plants. The roots grow down deep in the soil, making it rery popular in sections with limited rainfall. The fruit is very large, high colored and of excellent quality. It is famous for its delicate, rich, sub-acid flaror which makes it possible for the most confirmed dyspeptic to enjoy. We can recommend this variety to those looking for large fancy fruit.

\section{WARFIELD (Imp.)-}

The well known standard shipping and canning berry. Plants are vigorous and productive. Fruit nearly round, dark glossy red. firm and of good quality. Mid-season. This and Dunlap make a good, strong team.

\section{WM. BELT (Per).-}

This variety is large planted in some sections, while in others it is inclined to rust. It is a fancy variety that always brings fancy prices. It is quite productive, berries very large, roundish conical, color a bright glossy red, and the flaror good. Mid-season.

THE DESCRIPTION of the different varieties is as they have done with me at fruiting time. Varieties that I have not fruited I have given originator's description, or others', that I consider best authority.

Be sure to order early enough so that plants can be right at hand as soon as your ground is ready. Early setting pays big-the plants start quicker, grow better and make better beds than plants set late.

\section{Fall Bearing Strawberries}

The Everbearing Strawberry has been tested in every locality and has proven its value in every place where fair attention has been given it. The plants are absolutely hardy and with ordinary conditions you will get as good a crop in June as from the June varieties and with fairly farorable weather you will get berries from July until freezing weather. They will stand more freezing than other sorts. Try them.

\section{PROGRESSIVE (Per.)-}

This is a rigcrous, thrifty grower making a matted row of 2 or $3 \mathrm{ft}$. wide in fact, the best plant maker of all the fall bearing kinds. The color of the foliage manner and habit of growing somewhat resembles the Dunlap. The quality of the fruit is not ordinary medium, but is extraordinary, ranking with the very best. Mr. Harlow Rockhill of Iowa is the originator of this wonderful variety and he has reason to be proud of it. He says. "Progressive is a leader in the country." Keep blossoms picked off until about July if you want a full crop.

\section{AMERICUS (Per.)-}

One of the best known and the most prominent of the Everbearing. A seedling of the Pan-American. Plants are strong and deep rooted. The fruit is firm and medium to large in size, light red, and extra good quality. It is a fairiy good plant maker. It will produce fruit on the new plants as soon as well rooted.

\section{PEERLESS (Per.)-}

A variety which has proren successful. Plants are strong and deep rooted. It resembles Superb both in fruit and manner of growing.

\section{MASTODON (Per.)-}

This is anocher everbearer with big claims made for it. It originated in Indiana and was introduced from Michigan. Said to be fully as productive as Progressive: much larger: firmer and of good quality. It grows well and is certainly worthy of a trial. Wie recommend a trial of it. 

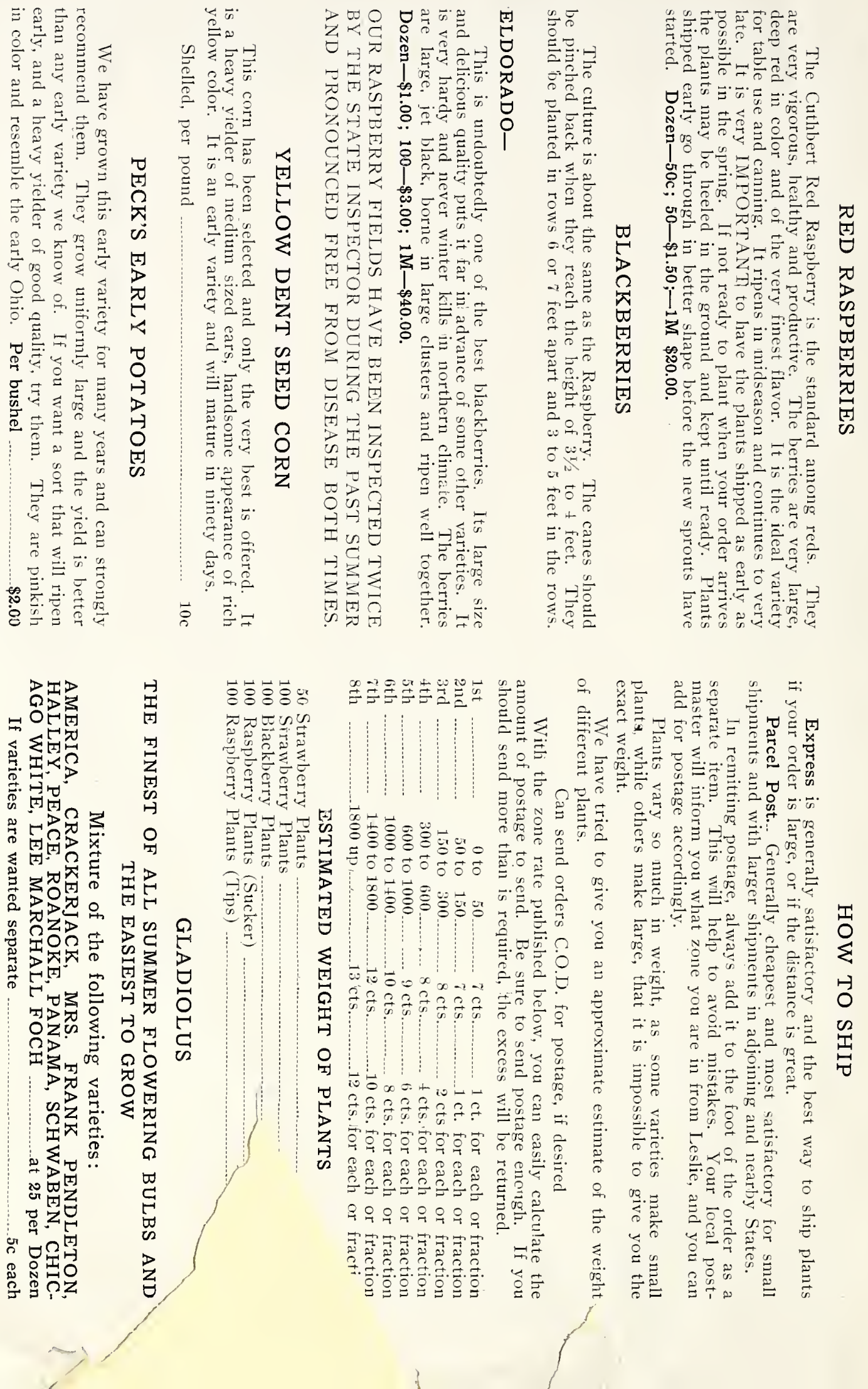


\section{PRICE LIST---Strawberries}

These prices are all F. O. B. Leslie, Michigan

$\mathrm{P}$-for Perfect; I-for Imperfect.

500 at 1000 Rate.

\begin{tabular}{|c|c|c|c|c|}
\hline & 25 & 100 & 250 & 1000 \\
\hline Aroma & .40 & .90 & 1.90 & 7.00 \\
\hline Abington & .35 & .75 & 1.85 & 6.00 \\
\hline August Luther & .30 & .70 & 1.75 & 5.50 \\
\hline Americus & 1.00 & 3.00 & & \\
\hline Bubach ......... & .40 & .90 & 1.90 & 7.00 \\
\hline Brandywine ..... & .35 & .75 & 1.85 & 6.00 \\
\hline Bederwood & .25 & .65 & 1.50 & 5.00 \\
\hline Chesapeake & .35 & .75 & 1.85 & 6.00 \\
\hline Clyde ............ & .40 & .90 & 1.90 & 7.00 \\
\hline Corsican & .35 & .75 & 1.85 & 6.00 \\
\hline Campbell's Early & .60 & 1.00 & 2.25 & 8.00 \\
\hline Cameron's Early & .35 & .75 & 1.85 & $6.0 \mathrm{j}$ \\
\hline Commonwealth & .35 & .75 & 1.85 & 6.00 \\
\hline Cooper & .60 & 1.00 & 2.25 & 8.00 \\
\hline Dr. Burrill & .25 & .65 & 1.50 & 5.00 \\
\hline Early Ozark & .35 & .75 & 1.85 & 6.09 \\
\hline Excelsior & .25 & .65 & 1.50 & 5.00 \\
\hline Gandy $\ldots . . . . .$. & .35 & .75 & 1.85 & 3.00 \\
\hline Gibson & .30 & .70 & 1.75 & 5.50 \\
\hline Glen Mary & .35 & .75 & 1.85 & 6.00 \\
\hline Hundred Dollar & .35 & .75 & 1.85 & 6.00 \\
\hline Haverland .......... & .40 & .90 & 1.90 & $\% .00$ \\
\hline Howatd No. 17 & .40 & .90 & 1.90 & 7.00 \\
\hline Kellogg's Prize & .40 & .90 & 1.90 & 7.00 \\
\hline King Wealthy. & .60 & 1.00 & 2.25 & 8.00 \\
\hline Lupton .......... & .35 & .75 & 1.85 & 6.00 \\
\hline Marshall & .35 & .75 & 1.85 & 6.00 \\
\hline Mastodon & 1.00 & 3.00 & & \\
\hline Premier & .35 & .75 & 1.85 & 7.00 \\
\hline Peerless. & .75 & 2.00 & & \\
\hline Pride of Michigan & .35 & .75 & 1.85 & 6.00 \\
\hline Parson's Bty. . & .35 & .75 & 1.85 & 6.00 \\
\hline Pennell ........ & .35 & .75 & 1.85 & 6.00 \\
\hline Progressive .... & .60 & 1.60 & 3.75 & 12.50 \\
\hline St. Louis & .25 & .65 & 1.50 & 5.00 \\
\hline Steven's Late Champion. & .30 & .70 & 1.75 & 5.50 \\
\hline Senator Dunlap & .25 & .65 & 150 & 5.00 \\
\hline Sample & .35 & .75 & 1.85 & 6.00 \\
\hline Uncle Jim & .35 & .75 & 1.80 & 6.00 \\
\hline$-1-1-1-1-1$ & .40 & .90 & 1.90 & $\% .00$ \\
\hline Warfield & .25 & .55 & 1.50 & 5.00 \\
\hline
\end{tabular}

\section{PER CENT DISCOUNT FOR EARLY CEDERS}

We will allow 10 percent discount on all orders accompanied by cash reaching us before March 15th for orders of 500 plants and over.

WRITE US FOR SPECIAL PRICES ON 5,000 PLANTS AND OVER 


\section{Garden Combination Offer Prepaid To Your Door.}

No. $1 \begin{cases}75 & \text { Senator Dunlap } \\ 75 & \text { Uncle Jim }\end{cases}$

No. $2\left\{\begin{array}{l}100 \text { Dr. Burrell } \\ 100 \text { Parsons Beauty }\end{array}\right.$

No. $3\left\{\begin{array}{l}100 \text { Progressive } \\ 100 \text { Mastodon }\end{array} \$ 4.50\right.$

CERTIFICATE OF NURSERY

INSPECTION

THIS IS TO CERTIFY, That we have examined the nursery

stock and premises of The E. W. Potter Co., Leslie, Michigan, and

find them apparently free from dangerous insects and dangerous con-

tagious tree and plant disease.

This certificate to be void after Sept. 15, :929.

STATE DEPARTMENT OF AGRICULTURE

Agricultural College, Michigan, Nov. 5. 1928. 